\title{
Influence of Demographic Characteristics of Participants on Consent to Genomic Research into Congenital Heart Disease
}

\author{
Charles Dupras ${ }^{1}$, Gregor Andelfinger ${ }^{2}$, Michèle Paré ${ }^{3}$, Maryse Thibeault ${ }^{2}$ and Béatrice Godard ${ }^{1^{*}}$ \\ ${ }^{1}$ Omics-Ethics Research Group, Department of social and preventive medicine, Public Health School, University of Montreal, Montréal QC, Canada \\ ${ }^{2}$ Research Center, Sainte-Justine Hospital, University of Montreal QC, Canada \\ ${ }^{3}$ Research Institute of Public Health, University of Montreal QC, Canada
}

*Corresponding author: Béatrice Godard, University of Montreal, Succursale Centre-Ville Montreal QC, Canada, Tel: 15143436111 (\#44036); Fax: 15143435646 ; E-mail: beatrice.godard@umontreal.ca

Rec date: Aug 25, 2014, Acc date: Oct 30, 2014, Pub date: Nov 2, 2014

Copyright: (c) 2014 Dupras C. This is an open-access article distributed under the terms of the Creative Commons Attribution License, which permits unrestricted use, distribution, and reproduction in any medium, provided the original author and source are credited.

\begin{abstract}
Background: The enrollment of sick children and their families in genomics studies calls for a comprehensive view of the consent process. Few studies have searched for correlations between the demographic characteristics of participants (age, gender, parental lineage) or their level of participation (affected children, parents, or other relatives), on the one hand, and patterns of consent to specific pediatric research procedures, on the other (DNA
\end{abstract} banking, use of cardiac tissue, disclosure of a cardiac condition, creation of cell lines, recall of a participant).

Objectives: This study sought to analyze the extent to which respondents' participation in genomic research into congenital heart disease, based on their consent to specific procedures, revealed patterns correlated with their demographic data.

Methods and findings: Data were abstracted from consent forms obtained from 600 participants enrolled in a research project on the genomics of congenital heart disease.

Results: Our analysis revealed significant patterns between demographic characteristics and willingness to consent to various aspects of genomic research into congenital heart disease.

Conclusions: Participant heterogeneity needs to be considered by clinical researchers in order to identify specific sub-groups of participants who may require more attention for improving the recruitment and retention in genomic research into congenital heart disease, as well as the consent process.

Keywords: Cardiovascular genetic research; Paediatrics; Consent process; Demographic characteristics

\section{Introduction}

The involvement of human participants in research is a cornerstone of scientific progress and its translation into clinical practice. A largely discussed question related to their recruitment into clinical research resides in how to adequately (ethically and efficiently) obtain consent from them. As a result, ethical issues related to the consent process have been discussed at length in the bioethics literature, stating that research participants should be informed about the benefits and risks of the research project before they give their consent, should understand what it is expected of them, and should have the competency and freedom to choose to participate to the research project - and be under no pressure to do so [1-6].

Parents' understanding and consent for the participation of minors in research is also an ethical issue addressed in the literature. Such proxy consent arguably represents a decision of higher complexity [7], as it implies fiduciary responsibilities on the part of parents. Hence, it is important that the perceptions of the parents about the research be assessed adequately so as to prevent misconceptions and minimize the possible limitations of some types of consent processes [8]. As for minors, it has been reported that they are able to apply their own assessment of the relative balance of risks and benefits of participating in genetic susceptibility research to make a decision about participating in a study [9]. As a result, it has been proposed that ethical guidelines should underline minors' ability to decide for themselves under some specific circumstances, when it can be justified [10].

It has been argued that improving communication between parents and investigators will increase trust and facilitate the recruitment of children in pediatric research [11]. Other factors have also been proposed as encouraging children's participation in research projects, such as the presence of both parents during the consent process [12], or a confirmation by the researchers that the results will be returned to them at the completion of the project [13]. However, few studies have examined other factors that may influence participation in research, such as demographic characteristics of participants (age, gender, parental lineage), their level of participation in research (affected children, parent, or other relative), or patterns of consent to specific pediatric research procedures (DNA banking, use of cardiac tissue, disclosure of a cardiac condition, creation of cell lines, recall of a participant). In this paper, we examine these factors as well as their mutual interrelations in the context of genomic research into congenital heart disease (CHD). This genomic research aimed to 
provide a comprehensive genomic analysis of the architecture of CHD, including left ventricular outflow tract obstructions (LVOTO), tetralogy of Fallot (TOF) and coronary atherosclerosis (CA), using both an analysis of structural genomic variation as well as a mutational survey of the entire coding sequence of the human genome. It was hypothesized that a comprehensive genomic analysis of CHD patients could identify causal variants, establish the molecular profile of a disease, replicate disease pathogenesis in model systems, and help develop novel approaches for intervention. Despite the expected benefits of such research, the investigators of the genomic project, here co-authors (GA and MT) perceived patterns of fear in participants and recurring misinterpretations throughout the consent process when they were seeing research participants at different visits. Participants could not recall what they had consented or what was the specific procedures to which they consented. Other participants were reluctant to certain procedures proposed in the consent form, despite the explanations given by researchers. As a result, we aimed to analyze the extent to which respondents' participation in genomic research into congenital heart disease, based on their consent to specific procedures, revealed patterns correlated with their demographic data. As a first step in improving communication between participants and CHD genomics research investigators, we gathered consent forms' data in order to better understand which sub-groups of research of participants would require more attention during recruitment consent. Our analysis revealed significant patterns between demographic characteristics and willingness to consent to various aspects of genomic research into congenital heart disease. Significant heterogeneity in research participants needs to be addressed to facilitate their recruitment and retention in paediatric genomic studies, as well as the consent process.

\section{Methods}

\section{Data collection}

Project approval was obtained from the Ste-Justine Hospital Research Center's Research Ethics Board. All consent forms signed between January 2009 and April 2012 were collected, that is to say, 600 consent forms, representing 172 families. From an initial sample including 982 consent forms, 382 forms were excluded because a particular question was not included: three consent forms (0.3\%) failed to mention the use of cardiac tissues for research; 272 forms $(27.7 \%)$ did not address the disclosure of a cardiac condition; 54 forms (5.5\%) did not have a question about cell lines; and 53 forms (5.4\%) did not raise the issue of recall. Prior to 2009, most consent forms did not require this information, thus explaining why older consent forms were excluded from this study.

In order to test for heritability and transmission of genetic cardiac conditions, participants were recruited among members of the nuclear family (i.e. mother, father, brothers and sisters) as well as among members from the distant family (e.g. aunts, uncles, cousins). There were three types of consent forms for three types of participants: 1) affected children, 2) unaffected minors and 3) unaffected adults. When a child was able to give his agreement to participate in the research project, (s)he could check for his assent on the informed consent.

Research participants were invited to indicate their consent to specific procedures contained in the consent forms (Answers are shown in Figure 1):

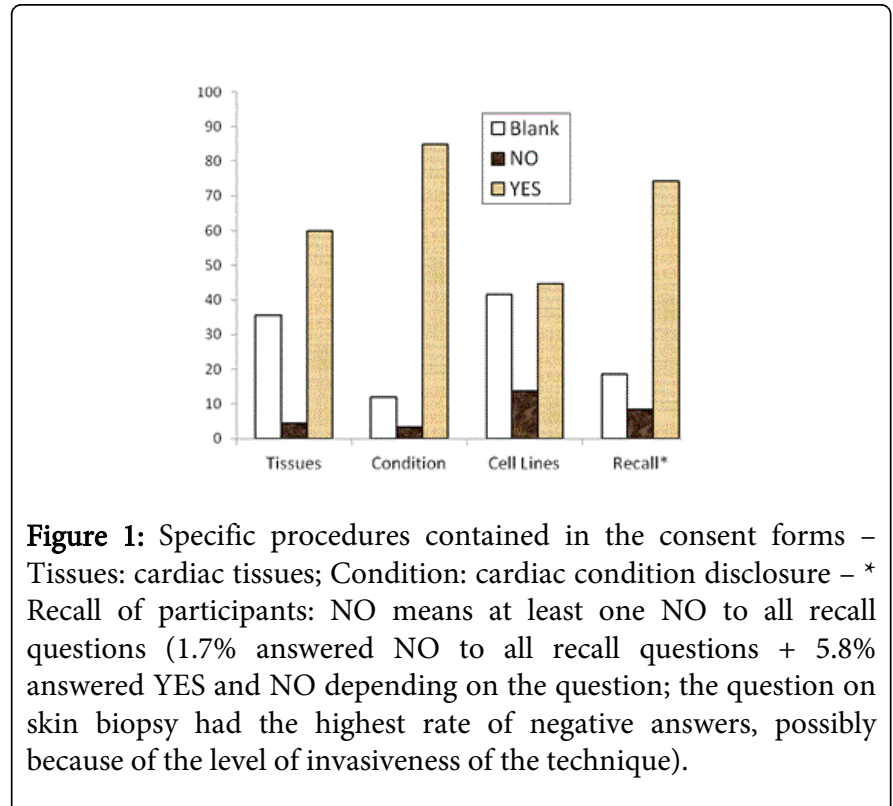

1. Cardiac Tissues: If you (your child) have (has) to undergo a surgical intervention for your (his/her) cardiac condition: I accept that the cardiac tissues that will be removed (from my child) during the intervention be stored in a bank for further research on cardiac disease. (yes/no)

2. Cardiac Condition Disclosure: In the situation where a cardiac condition is detected in me, I wish to be informed. (yes/no)

3. Cell Lines: I accept that an additional sample of blood be taken (from my child) for the creation of cell lines (immortal cells). (yes/no)

4. Recall: I authorize the research team to contact me again for more sampling (yes/no):

- For blood sample (DNA, RNA, proteins) (yes/no)

- For blood sample (cell lines) (yes/no)

- For skin sample (yes/no)

\section{Data analysis}

The management and merging of demographic information and the answers to the specific procedures presented above (See also Figure 1) as well as to DNA banking were collected and organized into an Excel file. Data were analyzed by a member of our research institute using the SPSS statistics software. The goal was to seek possibly meaningful relations between demographic information and the answers contained in the consent forms regarding participation in the CHD research project. Frequencies, correlations and $\chi^{2}$ tests were used. In addition, various charts were created to better visualize the differences among respondents. Statistical significance was considered a P-value of 0.05 or less. These analyses also allow us to better characterize the respondents.

\section{Statistical grouping}

In order to investigate possible associations, we grouped the data using three distinct and independent strategies. First, we used a 
Citation: Dupras C, Andelfinger G, Paré M, Thibeault M, Godard B (2014) Influence of Demographic Characteristics of Participants on Consent to Genomic Research into Congenital Heart Disease. J Clinic Res Bioeth 5: 199. doi:10.4172/2155-9627.1000199

Page 3 of 5

Consent Form Type (CFT) grouping, i.e., sorting the data according to the type of the consent forms (Table 1).

\begin{tabular}{|c|c|c|c|c|c|}
\hline & & $\begin{array}{l}\text { Affected } \\
\text { Children }\end{array}$ & $\begin{array}{l}\text { Unaffecte } \\
\text { d Minors }\end{array}$ & $\begin{array}{l}\text { Unaffected } \\
\text { Adults }\end{array}$ & Total \% (N) \\
\hline Total & --- & $28.7(172)$ & $19.3(116)$ & $53.0(312)$ & $100(600)$ \\
\hline \multirow[t]{2}{*}{ Gender } & Female & $39.0(67)$ & $52.6(61$ & $57.1(178)$ & $51.0(306)$ \\
\hline & Male & $61.0(105)$ & $47.4(55)$ & $42.9(134)$ & $49.0(294)$ \\
\hline \multirow[t]{3}{*}{ Age } & $0-2$ & $26.7(46)$ & $15.5(18)$ & --- & $10.7(64)$ \\
\hline & $3-17$ & $61.6(106)$ & $84.5(98)$ & --- & $34.0(204)$ \\
\hline & $18+$ & $11.6(20)$ & --- & $100(312)$ & $55.3(332)$ \\
\hline \multirow[t]{2}{*}{ Lineage } & Maternal & --- & $68.4(13)$ & $63.0(46)$ & $64.1(59 / 92)$ \\
\hline & Paternal & --- & $31.6(6)$ & $37.0(27)$ & $35.9(33 / 92)$ \\
\hline DNA & & $94.2(162)$ & $78.4(91)$ & $90.1(281)$ & $89.0(534)$ \\
\hline \multirow[t]{2}{*}{ Refusal } & Cell lines & $30.6(26 / 85)$ & $18.4(9 / 49)$ & $\begin{array}{l}21.6 \\
(40 / 185)\end{array}$ & $23.5(75 / 319)$ \\
\hline & $\begin{array}{l}\text { Cardiac } \\
\text { tissues }\end{array}$ & $1.9(3 / 156)$ & $6.9(4 / 58)$ & $\begin{array}{l}11.8 \\
(20 / 176)\end{array}$ & $7.0(27 / 384)$ \\
\hline \multirow[t]{2}{*}{ Recall } & $\begin{array}{l}\text { Unanswe } \\
\text { red }\end{array}$ & $15.5(24)$ & $28.0(30)$ & $16.5(47)$ & $\begin{array}{l}18.5 \\
(101 / 547)\end{array}$ \\
\hline & $\begin{array}{l}\text { Answere } \\
\text { d }\end{array}$ & $82.6(131)$ & $69.2(77)$ & $82.1(238)$ & $\begin{array}{l}81.5 \\
(446 / 547)\end{array}$ \\
\hline
\end{tabular}

Table 1: Consent Form Type-grouping - Demographics of research participants and specific procedures

\begin{tabular}{|l|l|l|l|l|l|l|l|}
\hline & & $\begin{array}{l}\text { Affec } \\
\text { ted } \\
\text { Child } \\
\text { ren }\end{array}$ & $\begin{array}{l}\text { Parent } \\
\mathbf{s}\end{array}$ & $\begin{array}{l}\text { Brother } \\
\text { s/ } \\
\text { Sisters }\end{array}$ & $\begin{array}{l}\text { Grand } \\
\text { parent } \\
\mathbf{s}\end{array}$ & $\begin{array}{l}\text { Other } \\
\text { Relatives }\end{array}$ & $\begin{array}{l}\text { Total \% } \\
\text { (N) }\end{array}$ \\
\hline Total & --- & $\begin{array}{l}28.7 \\
(172)\end{array}$ & $\begin{array}{l}34.5 \\
(207)\end{array}$ & $\begin{array}{l}15.7 \\
(94)\end{array}$ & $\begin{array}{l}3.8 \\
(23)\end{array}$ & $17.3(104)$ & $100(600)$ \\
\hline $\begin{array}{l}\text { Gende } \\
\mathbf{r}\end{array}$ & $\begin{array}{l}\text { Femal } \\
\text { e }\end{array}$ & $\begin{array}{l}39.0 \\
(67)\end{array}$ & $\begin{array}{l}56.5 \\
(117)\end{array}$ & $\begin{array}{l}51.1 \\
(48)\end{array}$ & $\begin{array}{l}60.9 \\
(14)\end{array}$ & $57.7(60)$ & $51.0(306)$ \\
\hline Male & $\begin{array}{l}61.0 \\
(105)\end{array}$ & $\begin{array}{l}43.5 \\
(90)\end{array}$ & $\begin{array}{l}48.9 \\
(46)\end{array}$ & $\begin{array}{l}39.1 \\
(9)\end{array}$ & $42.3(44)$ & $49.0(294)$ \\
\hline Age & $0-2$ & $\begin{array}{l}26.7 \\
(46)\end{array}$ & --- & $\begin{array}{l}12.8 \\
(12)\end{array}$ & --- & $5.8(6)$ & $10.7(64)$ \\
\hline $\begin{array}{l}17- \\
\text { Mar }\end{array}$ & $\begin{array}{l}61.6 \\
(106)\end{array}$ & --- & $\begin{array}{l}77.6 \\
(73)\end{array}$ & --- & $24.0(25)$ & $34.0(204)$ \\
\hline $18+$ & $\begin{array}{l}11.6 \\
(20)\end{array}$ & $\begin{array}{l}100 \\
(207)\end{array}$ & $9.6(9)$ & $\begin{array}{l}100 \\
(23)\end{array}$ & $70.2(73)$ & $55.3(332)$ \\
\hline $\begin{array}{l}\text { Lineag } \\
\text { e }\end{array}$ & $\begin{array}{l}\text { Mater } \\
\text { nal }\end{array}$ & --- & --- & --- & $\begin{array}{l}52.2 \\
(12)\end{array}$ & $68.1(47)$ & $61.4(59)$ \\
\hline $\begin{array}{l}\text { Pater } \\
\text { nal }\end{array}$ & --- & --- & --- & $\begin{array}{l}47.8 \\
(11)\end{array}$ & $31.9(22)$ & $35.9(33)$ \\
\hline DNA & & $\begin{array}{l}94.2 \\
(162)\end{array}$ & $\begin{array}{l}87.9 \\
(182)\end{array}$ & $\begin{array}{l}77.7 \\
(73)\end{array}$ & $\begin{array}{l}100.0 \\
(23)\end{array}$ & $90.4(94)$ & $89.0(534)$ \\
\hline
\end{tabular}

Table 2: Family Position-grouping - Demographics of research participants and DNA banking
Three CFT groups were formed: affected children $(n=172)$, unaffected minors $(n=116)$, and unaffected adults $(n=312)$. Second, we used a Family Position (FP) grouping, i.e., we sorted the data according to the position of the participant in the family (Table 2). Five FP groups were formed: affected children $(n=172)$, parents $(n=207)$, brothers/sisters $(n=94)$, grandparents $(n=23)$ and other relatives $(n=104)$. Other relatives (OR) represent family members such as cousins, aunts and uncles. Third, we sorted the data according to the architecture of CHD (Table 3). Out of the 600 consent forms, 5.2\% $(\mathrm{n}=31)$ were related to TOF, $54.8 \%(\mathrm{n}=329)$ to LVOTO, $18.3 \%(\mathrm{n}=110)$ to coronary atherosclerosis (CA) and $21.7 \% \quad(n=130)$ to other cardiovascular diseases.

\begin{tabular}{|c|c|c|c|c|c|c|}
\hline & & TOF & LVOTO & CA & Others & $\begin{array}{l}\text { Total } \% \\
\text { (N) }\end{array}$ \\
\hline $\begin{array}{l}\text { Participa } \\
\text { nts }\end{array}$ & --- & $5.2(31)$ & $54.8(329)$ & $\begin{array}{l}18.3 \\
(110)\end{array}$ & $\begin{array}{l}21.7 \\
(130)\end{array}$ & $100(600)$ \\
\hline \multirow{2}{*}{$\begin{array}{l}\text { Participa } \\
\text { nts' } \\
\text { Gender }\end{array}$} & Female & $\begin{array}{l}58.1 \\
(18)\end{array}$ & $47.4(156)$ & $\begin{array}{l}55.5 \\
(61)\end{array}$ & $\begin{array}{l}54.6 \\
(71)\end{array}$ & $51.0(306)$ \\
\hline & Male & $\begin{array}{l}41.9 \\
(13)\end{array}$ & $52.6(173)$ & $\begin{array}{l}44.5 \\
(49)\end{array}$ & $\begin{array}{l}45.4 \\
(59)\end{array}$ & $49.0(294)$ \\
\hline $\begin{array}{l}\text { Affected } \\
\text { Children } \\
\text { (AC) }\end{array}$ & --- & $5.8(10)$ & 64.5 (111) & $\begin{array}{l}14.0 \\
(24)\end{array}$ & $\begin{array}{l}15.7 \\
(27)\end{array}$ & $100(172)$ \\
\hline \multirow[t]{2}{*}{$\begin{array}{l}\text { AC'S } \\
\text { Gender }\end{array}$} & Female & $60.0(6)$ & $34.2(38)$ & $\begin{array}{l}50.0 \\
(12)\end{array}$ & $\begin{array}{l}40.7 \\
(11)\end{array}$ & $39.0(67)$ \\
\hline & Male & $40.0(4)$ & $65.8(73)$ & $\begin{array}{l}50.0 \\
(12)\end{array}$ & $\begin{array}{l}59.3 \\
(16)\end{array}$ & $61.0(105)$ \\
\hline \multirow[t]{2}{*}{ Consent } & Mother & $38.5(5)$ & 73.7 (115) & $\begin{array}{l}59.3 \\
(32)\end{array}$ & $18.6(8)$ & $70.3(187)$ \\
\hline & Father & $61.5(8)$ & $26.3(41)$ & $\begin{array}{l}40.7 \\
(22)\end{array}$ & $\begin{array}{l}81.4 \\
(35)\end{array}$ & $29.7(79)$ \\
\hline \multirow[t]{2}{*}{ Lineage } & Maternal & $100(3)$ & $44.1(15)$ & $\begin{array}{l}90.5 \\
(19)\end{array}$ & $\begin{array}{l}64.7 \\
(22)\end{array}$ & $64.1(59)$ \\
\hline & Paternal & 0() & $55.9(19)$ & $9.5(2)$ & $\begin{array}{l}35.3 \\
(12)\end{array}$ & $35.9(33)$ \\
\hline $\begin{array}{l}\text { Cell } \\
\text { Lines }\end{array}$ & $\begin{array}{l}100 \\
(19 / 19)\end{array}$ & $\begin{array}{l}70.6 \\
(113 / 16 \\
0)\end{array}$ & $\begin{array}{l}81.7 \\
(49 / 60)\end{array}$ & $\begin{array}{l}78.8 \\
(63 / 80)\end{array}$ & $\begin{array}{l}76.5 \\
(244 / 31 \\
9)\end{array}$ & \\
\hline
\end{tabular}

Table 3: CHD-grouping - Gender of research participants and respondents, lineage and consent to cell lines

\section{Results}

\section{Gender distribution}

Females represented $51 \%(n=306)$ and males $49 \%(n=294)$ of the respondents. First, gender distribution varied according to the CFT groupings (Table 1). $39 \%$ of the affected children were female, whereas $52.6 \%$ of unaffected minors and $57.1 \%$ of unaffected adults were female $(\mathrm{P}$-value $=0.001)$.

Second, gender distribution varied according to FP groupings (Table 2). Parents were more often mothers, whereas the brother/sister ratio was almost one. Female overrepresentation was true for parents (56.5\%), grand-parents (60.9\%) and other relatives $(57.7 \%)$ (P- 
value $=0.004)$, but not for brothers and sisters. Furthermore, we combined the groups of grandparents and other relatives and found that $61.4 \%$ of those participants - for which we could identify parental lineage - were associated with the maternal line, whereas only $35.9 \%$ were associated with the paternal one. Hence, the recruitment of participants from outside the nuclear family was also more difficult on the fathers' side.

Third, gender distribution varied according to the architecture of $\mathrm{CHD}$, as indicated in Table 3. In our sample, out of the 600 consent forms, $54.8 \%$ were related to LVOTO. Table 3 shows that LVOTO respondents were slightly more often male than female subjects, at $52.6 \%$. It was the opposite for the three other disease groups, where male proportion was $41.9 \%$ for TOF, $44.5 \%$ for CA, and $45.4 \%$ for other cardiovascular diseases. The difference in male participation between LVOTO and other diseases was statistically significant (Pvalue $=0.05$ ). Among affected children, LVOTO respondents were also more often male (65.8\%) than female subjects (34.2\%), which corresponds to the higher, incidence of LVOTO in males, at (2:1) in males versus females, whereas TOF incidence is $1: 1$ [14]. Only $52.5 \%$ of affected children were males in the other diseases groups (Pvalue $=0.05$ ).

Fourth, among parents who filled out a consent form for a minor, $70.3 \%$ were mothers and $29.7 \%$ were fathers. This rate varied according to disease, with the TOF group departing from the three others, since it was the only group where fathers were more often present at the signature of the consent form (61.5\%) (P-value $=0.005)$ (Table 3). It should be noted that most of affected children for whom TOF was detected were hospitalized at a very young age, and due to the severity of the disease, both parents must sign the consent form.

Age, family position and patterns of consent to specific research procedures: This section presents data on age and family position associated with patterns of consent to specific research procedures: DNA banking, creation of cell lines, use of cardiac tissue for further research, recall for more sampling and disclosure of cardiac conditions.

A DNA sample was collected, coded and stored for $89 \%$ of the participants. DNA banking participation rates varied amongst affected children (94.2\%), unaffected adults $(90.1 \%)$, and unaffected minors (78.4\%) (P-value=0.000) (Table1). Family Position of participants revealed that DNA was collected from all grandparents (100\%), but less often from brothers/sisters (77.7\%) (P-value=0.000) (Table 2). DNA banking also correlated, to some extent, with age: a DNA sample was collected for $90.7 \%$ of subjects over three years of age, but for only $75.0 \%$ of those under three $(\mathrm{P}$-value $=0.001)$. It is important to note that DNA banking was technically more difficult for participants under three because of the amount of blood required to isolate DNA. The highest consent rate was for the future disclosure of a cardiac condition to the participant, while the lowest rate was for the creation of cell lines.

The use of cardiac tissue for further research on cardiac disease was largely accepted. There was a small, but still significant difference between participants who refused the use of cardiac tissue for further research on cardiac disease: $1.9 \%$ of affected children refused as well as $6.9 \%$ of unaffected minors and $11.8 \%$ of unaffected (P-value $=0.002$ ). Thus, the age of the participant might play a role in consenting to the use of cardiac tissue.

On the contrary, refusal of consent to cell lines was higher for affected children $(30.6 \%)$ in comparison with the two other groups (unaffected minors and unaffected adults) (Table 1). Although this result was not statistically significant $(\mathrm{P}$-value $=0.07$ ), this still may represent a significant clinical issue, the $\mathrm{P}$-value being very dependent on our sample size. Furthermore, all TOF participants agreed to the use of their cells to build cell lines, in comparison to $70.6 \%$ of LVOTO participants (P-value $=0.02$ ) (Table 3). However, this difference could be specific to our research project as the result of a greater emphasis placed on the TOF group, based on the clinicians' scientific priorities.

Concerning the possibility of recalls for more tissue sampling, unaffected minors had a higher rate of unanswered questions on recall $(28 \%)$, in comparison to the affected children (15.5\%) or unaffected adults $(16.5 \%)(\mathrm{P}$-value $=0.017)($ Table 1$)$.

\section{Discussion}

Our study sought to analyze the extent to which respondents' participation in genomic research into congenital heart disease, based on their consent to specific procedures, revealed patterns correlated with their demographic data. Two conclusions can be drawn.

First, gender had an important influence on various aspects of research participation, such as proxy consent for minors, except for the TOF group, or the recruitment of distant family members. Such gender-associated patterns of participation in research raise socioethical questions. On one hand, considering that women consented to participate in this genomic research into congenital heart disease in a greater proportion than men, one might argue that we ought to inverse this dynamic by thinking of new strategies to facilitate the recruitment of men. Another study on newborn screening for fragile X syndrome in which the institutional review board had determined that consent was required from both parents also found a sizeable number $(158 / 262$, or $60.3 \%)$ of fathers who were not available for consent, reflecting the complexities of parental status and family relations and their implications for obtaining consent for research involving children. However, when fathers were available for consent, their acceptance rate $(71 \%)$ was slightly higher than that of the mothers (68\%) [15]. In our study, depending on the severity of the disease, fathers were more often available for consent: fathers filled out a consent form for children for whom TOF was detected and who were hospitalized. As we said, most of affected children for whom TOF was detected were hospitalized very young and due to the severity of the disease, both parents must be present at the signature of the consent form.

On the other hand, one might argue that women's participation in research or in recruiting distant family relatives might be part of a "gendered responsibility", i.e., responsibility that is socially assigned to women [16], and that any improvement of the consent process should strive to take this into account. Although the exceptions for parents who are deceased, unknown, incompetent, or do not have legal responsibility may be easier to apply, the exception for availability is at once the most likely reason for relying on one parent only and the least well defined. For example, in our study, were fathers "unavailable" simply because they were working, or does this criterion demand a more permanent or distant separation from the child? If the parents are divorced and living apart but both can be contacted, to what extent should investigators be obligated to seek permission from both? This requirement could grow as new technologies expand the medical conditions that can be identified during the study. If such conditions emerge as incidental findings for which there are treatments, then each parent's consent may be required. These were the types of questions 
Page 5 of 5

Nelson and his colleagues sought to address [15]. Clearly there are many variations on family structure that investigators should consider when planning research requiring permission from both parents.

There are a number of gendered aspects to pediatric research. It has been reported that studies of prenatal decision-making indicate that men are more likely to be "bystanders" in this process and that women bear the major responsibility for assessing genetic and testing risks. Studies also show that women are typically the "keepers" and key communicators of genetic information, taking on responsibility for disclosing genetic information to others and often bearing the burdens that it can impose [17].

Second, our data show that the age of participants might play a role in the consent to specific procedures of genetic research on CHD, such as DNA banking, recalls for more sampling, and use of cardiac tissue for further research. The protection of minors seems to be a priority among adult respondents. DNA was collected less often for children under three years old; however, parents were informed that DNA banking was technically more difficult for participants under three because of the amount of blood required to isolate DNA. We could see that a DNA sample was more often collected and from adults, and similarly, recalls for more tissue sampling were more often accepted for adults. In contrast, the use of cardiac tissues for further research was less often accepted for adults.

Recognizing 'sub-groups of participants' with different participation concerns and patterns of behaviour may lead to a greater awareness and understanding of the different needs of such subgroups regarding information, participation and consent. Participants in different sub-groups (e.g., according to gender, age, family position, disease investigated) may have different expectations towards research and different needs during the consent process, depending on the disease or on other demographic characteristics. Further studies could shed light on the effects of these factors on research participation.

Our analysis revealed patterns between demographic characteristics, participation and consent to various aspects of genomic research into congenital heart disease. Thus, it is important to pursue ongoing efforts to improve the overall recruitment process, so that it may better serve both future research participants and the advancement of science. We are aware that this is a tremendous task. Yet, attention should be given, while improving the consent process, to heterogeneity in the sample and the possibly different needs of different sub-groups of participants.

\section{Limits}

We cannot ignore the possible limitations of our study. First, the patients and family members from whom we have collected consent forms may not represent the full range of patients treated for congenital heart disease and their families at Ste-Justine Hospital for Children in Montreal. Second, in regard to gender, we don't know how many males and females were approached about the study but chose not to participate. Nor do we know whether the time of day when the recruitment occurred might affect response patterns and/or the availability of a particular parent or relative to complete the consenting process. It was recognized by our research team members that for very young children, mothers were more often available because they were often on maternity leave. Indeed, women are more likely to be caregivers for young children and would be more likely to be with children who were being enrolled in the study during the work day. Women would thus be more likely to complete consent documents on their children's behalf, as shown by our data.

\section{Acknowledgements}

This research and the work presented in the manuscript have been supported by a Genome Quebec grant.

\section{References}

1. Beskow LM, Friedman JY, Hardy NC, Lin L, Weinfurt KP (2010) Simplifying informed consent for biorepositories: stakeholder perspectives. Genet Med 12: 567-572.

2. Beskow LM, Friedman JY, Hardy NC, Lin L, Weinfurt KP (2010) Developing a simplified consent form for biobanking. PLoS One 5: e13302.

3. Jefford M, Moore R (2008) Improvement of informed consent and the quality of consent documents. Lancet Oncol 9: 485-493.

4. Patel PB, Gilchrist A, Cronan KM, Selbst SM (2010) Adequacy of informed consent for lumbar puncture in a pediatric emergency department. Pediatr Emerg Care 26: 739-741.

5. Porteri C, Borry P (2008) A proposal for a model of informed consent for the collection, storage and use of biological materials for research purposes. Patient Educ Couns 71: 136-142.

6. Shafiq N, Malhotra S (2011) Ethics in clinical research: need for assessing comprehension of informed consent form? Contemp Clin Trials 32: 169-172.

7. McKechnie L, Gill AB (2006) Consent for neonatal research. Arch Dis Child Fetal Neonatal Ed 91: F374-376.

8. Steven M, Broadis E, Carachi R, Brindley N (2008) Sign on the dotted line: parental consent. Pediatr Surg Int 24: 847-849.

9. Bernhardt BA, Tambor ES, Fraser G, Wissow LS, Geller G (2003) Parents' and children's attitudes toward the enrollment of minors in genetic susceptibility research: implications for informed consent. Am J Med Genet A 116: 315-323.

10. Coyne I (2010) Research with children and young people: The issue of parental (proxy) consent. Children \& society 24: 227-237.

11. Nabulsi M, Khalil Y, Makhoul J (2011) Parental attitudes towards and perceptions of their children's participation in clinical research: a developing-country perspective. J Med Ethics 37: 420-423.

12. Korotchikova I, Boylan GB, Dempsey EM, Ryan CA (2010) Presence of both parents during consent process in non-therapeutic neonatal research increases positive response. Acta Paediatr 99: 1484-1488.

13. Baret L, Godard B (2011) Opinions and intentions of parents of an autistic child toward genetic research results: two typical profiles. Eur J Hum Genet 19: 1127-1132.

14. Aboulhosn J, Child JS (2006) Left ventricular outflow obstruction: subaortic stenosis, bicuspid aortic valve, supravalvar aortic stenosis, and coarctation of the aorta. Circulation 114: 2412-2422.

15. Nelson DK, Skinner D, Guarda S, Choudhury S, Sideris J, et al. (2013) Obtaining consent from both parents for pediatric research: what does "reasonably available" mean? Pediatrics 131: e223-229.

16. d'Agincourt-Canning L (2001) Experiences of genetic risk: disclosure and the gendering of responsibility. Bioethics 15: 231-247.

17. Bailey DB Jr, Skinner D, Davis AM, Whitmarsh I, Powell C (2008) Ethical, legal, and social concerns about expanded newborn screening: fragile X syndrome as a prototype for emerging issues. Pediatrics 121: e693-704. 